\title{
Drug-Induced Parkinsonism and Other Movement Disorders
}

\author{
R.T. Ross
}

\begin{abstract}
This is a review of reserpine, haloperidol, and various phenothiazines that produce parkinsonism and other movement disorders. The by-products of illicit meperidine synthesis, MPTP and its more sinister companion, MPP, are also discussed. Movement disorders, transient or fixed, frank parkinsonism and/or dyskinesia, due to a variety of other medications and toxic agents are included. These are methanol, lithium, methyldopa, antimetabolites, antidepressants, sympathomimetic anorexiants, some types of antihistamines, and various combinations of agricultural chemicals.
\end{abstract}

RÉSUMÉ: Parkinsonisme et autres anomalies du mouvement induits par des médicaments Nous revoyons la réserpine, l'halopéridol et différentes phénothiazines qui provoquent le parkinsonisme et d'autres anomalies du mouvement. Nous discutons également de dérivés de la synthèse illégale de la mépéridine, le MPTP et son compagnon encore plus sinistre, le MPP. Nous incluons les anomalies du mouvement, qu'elles soient passagères ou fixes, le parkinsonisme franc et/ou les dyskinésies, dus à une variété d'autres médicaments et agents toxiques. Ces agents toxiques sont le méthanol, le lithium, le méthyldopa, les antimétabolites, les antidépresseurs, les anorexiants sympathicomimétiques, certains types d'antihistaminiques et différentes combinaisons de produits chimiques agricoles.

Can. J. Neurol. Sci. 1990; 17:155-162

Secondary parkinsonism has received increased attention since the illicit use and manufacture of the neurotoxin 1-methyl4-phenyl-1,2,3,6 tetrahydropyridine (MPTP). 1,2 It has been suggested that idiopathic Parkinson's disease may be due to some similar substance. ${ }^{3,4}$ The age of onset and mortality of Parkinson's disease over the last half century makes this unlikely. The common form of the disease remains idiopathic. ${ }^{5}$ Eldridge and Rocca ${ }^{6}$ have emphasized the unchanging death rate and the age-specific incidence rates over the past fifty years $5,7,8$ (Figure 1). The disease does not commonly occur in clusters or particular geographic areas, and is of extremely low concordance in monozygotic twins, There are rare kindreds with the disease. Calne et $\mathrm{al}^{9}$ reported six families in which the symptoms occurred over a short period of time but with a great range in age of onset. This suggests an environmental rather than genetic cause. The family reported by Golbe et al ${ }^{10}$ contained 27 patients over four generations. The inheritance was autosomal dominant, male to male, and afflicted members lived in both Italy and America. The age of onset was $47 \pm 9$ and age of death $56 \pm 8$.

Parkinsonism may result from infection, hypoxaemia, hypoglycaemia, metallic intoxication, possibly trauma, brain tumour, 11 and from an increasing number of medications. This paper deals with parkinsonism plus other basal ganglia signs and symptoms attributable to drugs and some of these other factors.

\section{Rauwolfia Alkaloids; Reserpine}

There is a curious feature common to several totally unrelated classes of both ancient and modern medications used to treat the insane. When effective they produce parkinsonism or other signs of a striatal disorder, i.e. tics, dystonia, torsion spasm, catatonia, etc. Reserpine, effective treatment for psychosis and hypertension, 12 depletes dopamine and other catecholamines from the brain and adrenal medulla by interferring with presynaptic vesicular storage while monoamine oxidase degradation perseveres.

The modern understanding of Parkinson's disease was associated with the widespread use of reserpine and the recognition by Carlson and colleagues in $1957^{12}$ that it produced the disease by dopamine depletion. Further, they showed that parkinsonian manifestations and diminished brain dopamine could both be reversed with parenterally administered dopa.

Levodopa will reverse reserpine-induced parkinsonism in both humans and animals as will apomorphine and amphetamine, both dopamine agonists. Amphetamine does so by releas- 


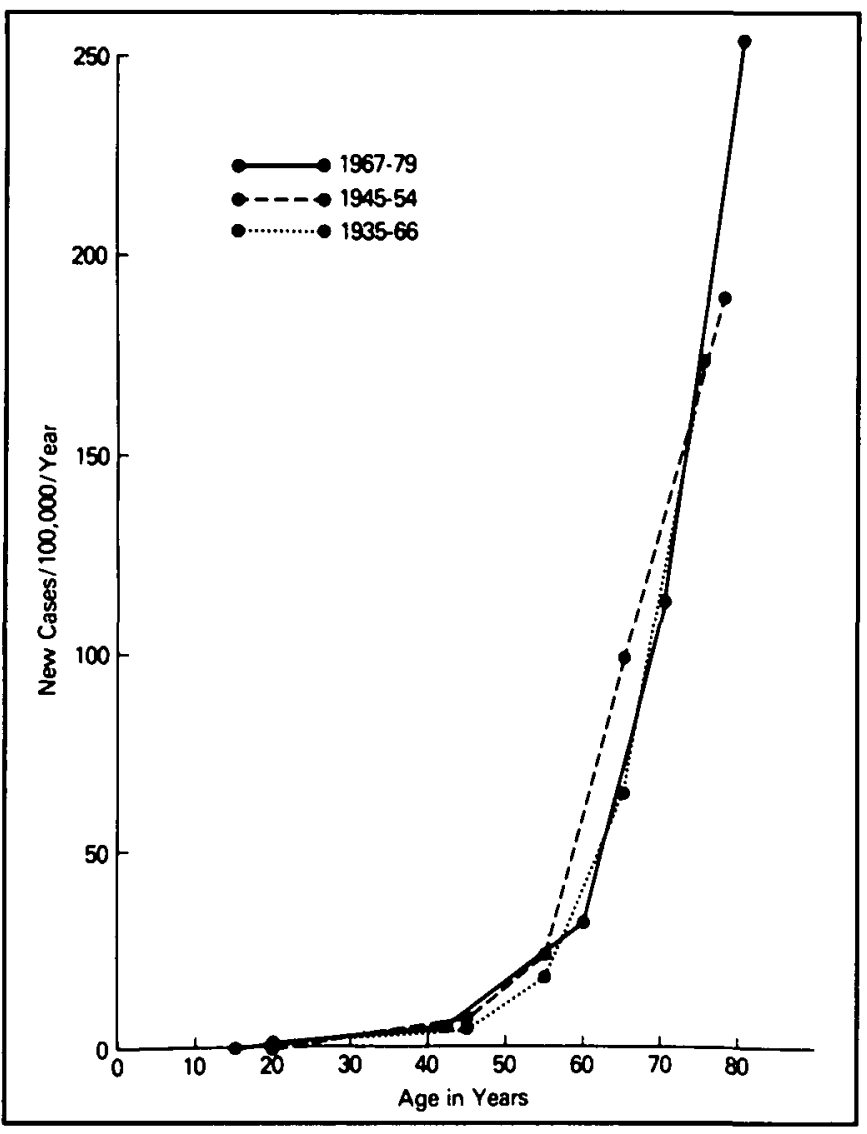

Figure I-Average annual age-specific incidence rates for parkinsonism in Rochester, Minnesota, in three epochs.

(Reproduced with permission from The New England Journal of Medicine 1985; 313(8): 1159-1160 and Dr. Roswell Eldridge.)

ing unbound dopamine while reserpine depletes the vesiclestored bound dopamine. 13

\section{Haloperidol}

Haloperidol, 4-[4-(4-chlorophenyl)-4-hydroxy-1-piperidinyl]-1-(4-fluophenyl)-1-butanone was synthesized in 1958 by Janssen and Jageneau. ${ }^{14}$ Its structure resembles meperidine, and it was the attempt to illicitly manufacture the latter that resulted in MPTP which produced permanent, severe, parkinsonism in a number of young drug addicts. ${ }^{1}$ Although haloperidol shares the three ring nucleus of the phenothiazines, it more closely resembles the 4-phenylpiperidines related to meperidine.

It is considered to have less anticholinergic effects and greater extra-pyramidal producing effects than the phenothiazine neuroleptic drugs. Dyskinesiae occur in up to $50 \%$ of patients treated with haloperidol. ${ }^{15}$ Dystonias (of eye movement, neck, lip, jaw, tongue, face, and throat) are more common in young adults and children, particularly with dehydration, and are said to be twice as common in men as in women. Parkinsonism is more common in women and the elderly. Dyskinesiae may be immediate or appear weeks or months after the initiation of therapy, ${ }^{16,17}$ while akathisia, dysphoria, and anxiety have been reported after a single dose in normal subjects. 18

The adverse effects of the drug always appear to be reversible when it is stopped and may be ameliorated by a vari- ety of agents even when it is continued. These include amantadine hydrochloride, ${ }^{19}$ diphenhydramine, ${ }^{20}$ and benzotropine. ${ }^{21}$

Haloperidol blocks striatal post-synaptic dopamine receptors. ${ }^{22}$ Piribedil, a dopamine receptor agonist, reduces parkinsonian manifestations when given in high doses. ${ }^{23}$ In lower doses, it has antimanic properties and would seem to be the ideal adjunctive medication with haloperidol for the treatment of schizophrenia. Paradoxically, when given to schizophrenic patients in combination (low dose piribedil), all showed marked akinesia and rigidity. Either drug alone produced mild or no parkinsonism. ${ }^{22}$ It has been suggested that low dose piribedil may have a preferential action on a particular type of dopamine receptor that "inhibits dopaminergic nerve activity and dopamine synthesis" (Carlsson, 24 Bunney and Aghajanian ${ }^{25}$ ). Further, there is evidence that stimulation of some dopamine receptors inhibits dopamine synthesis and the electrical activity of dopamine neurons. Low dose piribedil can selectively stimulate these receptors in animal and man. The effect of these two agents in combination, therefore, would be blockade of post-synaptic dopamine receptors by haloperidol while the low dose piribedil would counteract the "compensatory increase in firing rate and dopamine synthesis by dopamine neurons secondary to the blockade". 22 This would potentiate the blockade of dopaminergic activity and compound the rigidity and akinesis.

\section{Phenothiazines}

Parkinsonism due to neuroleptic (antipsychotic) medication has been recognized since the 1950 's. ${ }^{26}$ The action of the phenothiazines is similar to the butyrophenones (blockage of postsynaptic dopamine receptors) and unlike reserpine (dopamine depletion).

The neuroleptics (reserpine, butyrophenones, and phenothiazines) are all nerve impulse blocking agents and are also potent dopamine-releasing agents, possibly by potentiating exocytosis as well as membrane expansion and fluidization. ${ }^{27}$

These effects could increase spontaneous secretion of dopamine which in turn would disinhibit tyrosine hydroxylase 28,29 presynaptically allowing more dopamine synthesis locally and intraneuronally. $30,31,32$

Seeman et al, in a review of the membrane actions of neuroleptics in relation to drug-induced parkinsonism and tardive dyskinesia have suggested a presynaptic site. ${ }^{33}$

It is possible to identify in advance the patients most likely to develop phenothiazine-induced parkinsonism. Crowley et al found that psychiatric patients who excreted larger amounts of urinary free dopamine before treatment were significantly less likely to develop phenothiazine-induced parkinsonism than patients excreting smaller amounts. ${ }^{34}$

The individual sensitivity to phenothiazine and its duration has been demonstrated by Cahan and Parrish. 35

Some patients develop parkinsonism on a small dose of phenothiazines after a few days of treatment, some only after large doses, and some never, irrespective of the dose or duration. Factors that increase the likelihood of a patient developing parkinsonism from this class of drugs are advanced age, female gender, ${ }^{36}$ higher doses, coexisting organic brain disease, and the use of the powerful piperazine side chain phenothiazines, plus the important but unidentifiable, individual sensitivity. 
Preclinical or latent Parkinson's disease readily predisposes patients without overt manifestations of the disease to druginduced parkinsonism. ${ }^{37}$ Rajput et al described two patients with parkinsonism secondary to neuroleptics with remission of all signs when the drugs were withdrawn. Histological examination subsequently showed the characteristic abnormalities of idiopathic Parkinson's disease. Homovanillic acid levels were low in both and dopamine was reduced in the striatum of one. ${ }^{38}$ Similar information was found by Wilson and Primrose ${ }^{39}$ by following 48 patients with drug-induced parkinsonism initially reported by Stephen and Williamson. 40

There is a certain capriciousness in the relationship between the duration and size of the dose of neuroleptics and the time of onset of extrapyramidal symptoms. When a large dose is given, particularly if intramuscular, dyskinesiae will be seen in 24 to 48 hours. In contrast, Kruse reported three psychotic patients with no extrapyramidal signs when on 20 to $45 \mathrm{mgs}$ of fluphenazine, all of whom developed parkinsonism with facial dyskinesiae when the dose was reduced to 2 to $5 \mathrm{mgs}$ per day. ${ }^{32}$ These symptoms abated within days when the medication was stopped.

Both parkinsonism and the acute distressing hyperkinetic states which occur at the beginning of treatment with phenothiazines are more common in women. The latter are predominantly face, head, neck, mouth, and tongue dystonias, torsions, grimaces, and tics. The limbs may also be involved. Delay et al ${ }^{42}$ noted the similarity of these movements to the post-epidemic encephalitis "excito-motor" syndromes described by Marie and Levy in 1920.43,44,45

Hunter et al have studied phenothiazine dyskinesiae by surveying 450 mental hospital patients. 46 All were demented, only women ( 200 of the 450 ) were affected, and the incidence of the movement disorder was $5 \%$. The interval from the start of phenothiazines to the onset of the movements varied from 18 months to five years. The doses were conventional. The majority had also developed parkinsonism for which they were being treated. Eight months to three years after cessation of the phenothiazines, the movements persisted unchanged. 46

Klawans et al have reported the persistence of neuroleptic induced parkinsonism for 18 months after the drug was stopped, with eventual complete recovery. 47 Hirschberg's 40 year old patient lost her phenothiazine induced parkinsonism only 20 months after the medication was stopped. 48 Dyskinesiae and akathisia both may persist long after phenothiazines have been stopped. 49 Additionally, parkinsonian symptoms may worsen after the withdrawal of neuroleptic medication. 50

The fact that parkinsonism is drug-induced is not always obvious and the past and current history of drug consumption is often forgotten or minimized particularly in the elderly. Murdoch and Williamson described "occult" drug-induced parkinsonism 51 and Stephen and Williamson 40 found that half of 95 new cases of parkinsonism referred to a geriatric department were unknowingly drug-induced or drug aggravated. Two-thirds of these lost their parkinsonism when the medication was stopped, some taking as long as 36 weeks to do so.

Drug-induced dyskinesiae do not often occur simultaneously with drug-induced parkinsonism and need not be "tardy". Either movement disorder may appear or worsen after medication is stopped. Crane has reported withdrawal dyskinesiae after all neuroleptics were discontinued and this was significantly more common in patients who had previously displayed drug-induced parkinsonism. 52

Patients with acquired immuno-deficiency disease (AIDS) appear to be unusually sensitive to the extrapyramidal sideeffects of phenothiazines, even low potency drugs such as prochlorperazine. ${ }^{53} \mathrm{HIV}$ infection is neurotropic and may render AIDS patients more susceptible to the central nervous system effects of even the milder phenothiazines.

In addition, AIDS patients are known to be subject to a variety of movement disorders, independent of medication and sometimes before other manifestations of AIDS appear. ${ }^{54}$

\section{Meperidine-Analog Synthesis}

A major turn occurred in the understanding of parkinsonism with the report of Davis et al in 1979.55 Their patient was manufacturing 1-methyl-4-phenyl-4-propionoxy-piperidine (MPPP) for his own intravenous use. He had done this without undesired side-effects for some months, until a change in the process resulted in a mixture of MPPP and 1-methyl-4-phenyl-1,2,4,6tetrahydropine (MPTP). The injection of the combination resulted in marked parkinsonism that persisted for 18 months and responded to treatment. Autopsy two years later revealed nerve cell loss in the zona compacta of the substantia nigra with extraneuronal melanin and melanin within microglia cells plus an astrocytic response. A single (possible) Lewy body was seen. Four years later, Langston et al reported the same permanent result in four young people who were also synthesizing "synthetic heroin" for their own use. ${ }^{1}$

Further information suggested that MPTP was toxic when inhaled or absorbed through the skin. A chemist synthesizing the substance for legitimate purposes in his own laboratory from 1964 onward developed parkinsonism in 1970 at age 38 . The disease has progressed with some response to conventional therapy. 57

The mechanism of action of MPTP is clearly important. Selegiline, a monoamine oxidase inhibitor, is protective suggesting that some product of oxidation causes the damage. 58,59 Melanin affinity of MPTP is part of the answer. Loss of this pigment and degeneration of the cells containing it are conspicuous features of Parkinson's disease 60 and manganese induced parkinsonism (monkey) produces a similar lesion in melanin containing cells. ${ }^{61}$ MPTP has a high melanin affinity for both isolated beef eye melanin and synthetic dopamine melanin in vitro. ${ }^{62}$ Further, tritiated MPTP binds to brain membranes with very high receptor densities in the caudate, substantia nigra, and locus coeruleus in the human brain.

It has been suggested that MPTP may not be the neurotoxic agent but the conversion of MPTP to 1-methyl-4-phenylpyridinium (MPP) results in the true toxic substance. ${ }^{63,64}$

There are biochemical similarities and differences in Parkinson's disease and MPTP-induced parkinsonism. In both, the cerebrospinal fluid level of homovanillic acid (the major dopamine metabolite) is reduced while 5-hydroxyindolacetic acid (the major serotonin metabolite) is normal. The cerebrospinal fluid level of 3-methoxy-4-hydroxyphenylethylene glycol (the major metabolite of brain norepinephrine) was elevated in MPTP parkinsonism and reduced in Parkinson's disease. While central norepinephrine containing neurons are abnormal in Parkinson's disease they are not in the MPTPinduced state. 65 
In humans, tritiated MPTP binds densely to the substantia nigra of both normal and idiopathic parkinsonian brains in spite of the loss of dopaminergic neurons in the latter. This further supports the contention from animal work that MPTP binds to an extraneuronal enzyme, monamine oxidase converting it to a toxic substance which then accumulates intraneuronally. ${ }^{66}$ In animal studies the pathogenic metabolite that accumulates within the dopaminergic neurons is MPP. ${ }^{67}$ In parallel studies using tritiated pargyline and tritiated MPTP the binding sites were found to be almost identical. 66

Although MPP appears to be the toxic metabolite of MPTPinduced parkinsonism and the conversion is via a monamine oxidase, the molecular mechanism has not been established. Conversion to a free radical or uptake by mitochondria and inhibition of mitochondrial respiratory enzymes, leading to calcium release and cell death have been suggested. ${ }^{68}$ Blair et al found that MPTP inhibited dihydropteridine reductase (DHPR). ${ }^{69}$ This enzyme regenerates the coenzyme tetrahydrobiopterin required for dopamine formation. ${ }^{70}$ Further, there may be two sources of cytotoxic oxygen-derived free radicals causing neuronal loss: one derived from the oxidation of catecholamines, and the other from the conversion of MPTP. ${ }^{71}$

Forno et al have augmented the MPTP-induced lesions in the squirrel monkey brain by giving the drug over a longer time to older animals. ${ }^{72}$ They found the usual substantia nigra lesions plus lesions in the locus coeruleus as well as eosinophilic inclusion bodies. The latter were only in areas where Lewy bodies are customarily present in human Parkinson's disease. Subsequent electron microscopic examination of these objects revealed they were not Lewy bodies. ${ }^{73}$

\section{Various Substances Causing Movement Disorders}

\section{Organophosphate insecticides}

Malathion ${ }^{\circledR}$ and Parathion ${ }^{\circledR}$ may produce transient or permanent central or peripheral nervous system abnormalities. They competitively inhibit the acetylcholine metabolizing enzyme, acetylcholinesterase. Davis et al ${ }^{74}$ reported a cropduster who had several episodes of acute intoxication with malathion and parathion. He took $1.0 \mathrm{mg}$ atropine tablets to relieve the nausea, diaphoresis and diarrhea that recurred with each attack. He developed right-sided tremor and stiffness after eight years of exposure to the two substances. Treatment with levodopa was not helpful. The authors speculate that his parkinsonism could have been related to increased cholinergic activity rather than decreased dopaminergic activity.

\section{Organic Solvents and Mercury}

Ohlson and Hogstedt 75 assessed 91 parkinsonian patients for occupational exposure to carbon disulfide, agricultural chemicals, and mercury. The controls were 75 patients, age and residency mated, with subarachnoid hemorrhage (SAH) from the same hospital population. There were no significant differences in exposure frequency to organic solvents.

Barbeau and Roy reported a high correlation between Parkinson's disease and pesticide use in Quebec. ${ }^{76}$ Bocchetta and Corsini have reported two cases of early age parkinsonism associated with pesticide exposure. ${ }^{77}$ One had been exposed to chlorinated cyclodienes and carbofuran as well as chlorophenoxy herbicides. The other had worked in a chemical plant mak- ing petroleum derivatives and pesticides, largely morpholine compounds.

In addition, Peters et al have linked incipient or manifest parkinsonism in grain storage workers to the use of liquid-solvent fumigants and pesticides, principally a carbon disulphide/carbon tetrachloride mixture. ${ }^{78}$ Carbon disulphide alone has a known association with parkinsonism ${ }^{79}$ and carbon tetrachloride has also been incriminated as a cause of parkinsonism. ${ }^{80}$ Disulfiram (antabuse) is metabolized to carbon disulphide and an example of peripheral neuropathy and transient parkinsonism after ingestion of large amounts of the former has been reported. 81

Peters et al have also reported parkinsonism after the inadvertent ingestion of the fungicide hexachlorobenzene. 82

Paraquat, a herbicide similar in structure to MPTP, has been suggested as a possible neurotoxin capable of producing parkinsonism. Although water soluble and unable to penetrate the blood brain barrier and not metabolized into a substance which might penetrate the blood brain barrier it may be reduced outside the body into a substance that can.

Sanchez-Ramos et al have reported a citrus farmer with 15 years of exposure to paraquat and the development of parkinsonism at age $32^{83}$ but Koller has presented reasons why paraquat is probably not the etiological agent. 84,85

\section{Methyldopa}

This substance, 3-hydroxy-a-methyl-L-tyrosine, is useful in the treatment of arterial hypertension by reduction of central sympathetic outflow.

It inhibits L-amino acid decarboxylase and similar to dopa is successively decarboxylated and hydroxylated to form the false neurotransmitter, a-methylnorepinephrine, which displaces norepinephrine. Methyldopa is a competitive inhibitor of dopa decarboxylase essential to the conversion of dopa to dopamine. In addition, the false neurotransmitter a-methyl-norepinephrine, may compete with dopamine for post-synaptic receptors in the striatum. ${ }^{86}$

Frank, transient, parkinsonism or aggravation of pre-existing parkinsonism in association with methyldopa has been reported by Groden, ${ }^{87}$ Peaston, ${ }^{88}$ Strang, ${ }^{89}$ and others.

\section{Alcohols \\ Ethanol}

It has been suggested that alcohol can facilitate the emergence of drug-induced parkinsonism and lower the tolerance to neuroleptic medication. The suggested mechanism is the selective impairment of the tyrosine hydroxylase enzyme system. ${ }^{90}$ Akathisia and dystonia related to neuroleptic medication also appear to have been precipitated by alcohol. ${ }^{91}$ Seven chronic alcoholics demonstrated transient parkinsonism from alcohol withdrawal or chronic intoxication. 92

In contrast, Lang et al examined the drinking habits of 125 patients with Parkinson's disease and found no difference in the amount of alcohol consumed by a control population. ${ }^{93}$ Koller reported the same findings as well as minimal changes in parkinsonian symptoms after the controlled infusion of intravenous alcohol. 94

\section{Methanol}

McLean et al reported two survivors of methanol poisoning. ${ }^{95}$ They developed parkinsonism, blindness, and dementia. 
CT scans showed bilateral symmetrical infarction of the frontocentral white matter and putamen. At autopsy, cystic resorption of the putamen and fronto-central white matter as well as neuronal damage throughout the cerebrum, cerebellum, brainstem, and spinal cord, were found. ${ }^{95} \mathrm{~A}$ similar case has been described by Ley and Gali. ${ }^{96}$

\section{MiscellaneOUS}

\section{Lithium}

Acute parkinsonism has occurred in a manic depressive patient treated with $900 \mathrm{mgs}$ of lithium per day for the previous five years. Lithium serum levels had varied between 0.74 $\mathrm{mEq} / \mathrm{L}$ and $1.1 \mathrm{mEq} / \mathrm{L}$ with no neurotoxic side effects but for an occasional fine tremor of the hands. Acute parkinsonism was precipitated by a trial on a liquid protein diet producing a rise of lithium to toxic levels. The signs were promptly reversed when the lithium dosage was reduced by a third, the diet was discontinued, and benztropine mesylate (Cogentin ${ }^{\circledR}$ ) was given. ${ }^{97}$

\section{Carbon Monoxide}

There are many reports of parkinsonism after exposure to carbon monoxide and some with an unusually prolonged interval following the exposure. ${ }^{98}$ The clinical picture may be either pure parkinsonism or a mixed state of apathy, dementia, plus parkinsonian features.

\section{Hypoglycaemia}

Sulphonylurea induced a reversible parkinsonism in a 63 year old diabetic. He had been treated with Tolbutamide ${ }^{\circledR}$ for years and had recently reduced his food intake to 600 calories per day. The following week he was withdrawn and confused and became unconscious. After intravenous dextrose he recovered consciousness and in the next few days developed tremor, rigidity, dysarthria and a mask-like face, all of which disappeared after a week. ${ }^{99}$

\section{Antineoplastic Agents}

A combination of vincristine and adriamycin has produced head and limb tremor as well as a "parkinsonian-like syndrome" in a nine month old child with leukemia. 100 5-fluorouracil has also produced a neurological syndrome consisting of ataxia, masked facies, weakness, rigidity and tremor, increased by voluntary movement. The signs vanished when the drug was discontinued and reappeared with a second trial. ${ }^{101}$

\section{Antidepressants}

The tricyclic antidepressant, amoxapine, is a metabolite of the neuroleptic loxapine. Although used as an antidepressant, it has established antidopaminergic properties. ${ }^{102,103}$

Steele 104 has reported an example of torticollis, tongue protusion, and eye deviation dystonia in a 27 year old man after two days of amoxapine. All symptoms were reversed within onehalf hour after he was given $50 \mathrm{mg}$ of diphenydramine intramuscularly. Thornton and Stahl have described a 49 year old woman who developed both parkinsonism and dyskinesia after being treated for depression with amoxapine ${ }^{105}$ while the patient of Lesser developed dyskinesia only after withdrawal of the drug. 106

Perhaps paradoxically, there are reports of drug-induced dyskinesiae (from neuroleptics and L-dopa) improving after the patient was started on the tricyclic, desipramine hydrochloride. ${ }^{107}$ The authors suggested that the antidepressant may decrease beta-adrenoreceptor sensitivity and density which in turn diminishes dopamine release.

Imipramine hydrochloride was tested as a therapeutic agent for parkinsonism in a doubleblind placebo study in 1965 by Strang. 108 The results were strongly in favour of the benefits of the drug and were independent of any improvement in depression.

\section{Monamine Oxidase Inhibitors}

These substances, selegiline (Deprenyl ${ }^{(*)}$ ) and tranylcypramine sulphate (Parnate ${ }^{(\otimes)}$ ) improve the symptoms of parkinsonism probably by increasing the availability of dopamine in the striatum. The former is said to have the advantage of not carrying the "old cheese and red wine" precautions. ${ }^{109}$ Teusink et al have reported the development of parkinsonism in a 75 year old lady after her depression was treated with the MAOI phenelzine. 110 The parkinsonism cleared when the drug was stopped and they offer several explanations for this yet another paradoxical example of the relationship between the relief and the cause of a disease by a single agent.

\section{Stimulants}

Methylphenidate (Ritalin ${ }^{\circledR}$ ) probably has central dopaminergic properties. It can cause chorea in minimally brain damaged children and in apparently normal family members at risk for Huntington's disease. 111 Persistent shoulder tics have occurred in another child treated concurrently with methylphenidate plus thioridazine. 112 The movements stopped promptly with the administration of haloperidol, a potent dopamine blocking agent. Other stimulants like dextro-amphetamine and pemoline cause movement disorders (tics, chorea) and worsen tardive dyskinesiae. Methylphenidate and amphetamine increase presynaptic dopamine release and also block the re-uptake. ${ }^{113}$ Clearly the common feature among the agents that cause chorea and similar movements (d-amphetamine, methylphenidate and levodopa in parkinsonism) is the ability to increase cerebral dopamine. In the last of these situations denervation hypersensitivity may contribute to the problem but as the prevalence of the dyskinetic movement is directly proportional to the duration of exposure to the drug, denervation is not the whole answer.

Amphetamine 114 and contraceptives 115,116 can each produce chorea. Psychosis and chorea appeared in a young woman 48 hours after starting amphetamine. She had been on oral contraceptives for 10 years. ${ }^{116}$

Amphetamine releases norepinephrine from central noradrenergic neurons and epinephrine increases rigidity and tremor in Parkinson's disease. 117 Increasing brain norepinephrine in the guinea pig inhibits tyrosine conversion at the hydroxylase level blocking the initial catecholamine metabolic step, i.e. tyrosine to dopa. 28

Another sympathomimetic agent, phenylpropranolamine, is used with caffeine as an anorexiant. It has caused catatonic posturing and cogwheel rigidity in a patient previously treated with doxepin hydrochloride and fluphenazine. The signs were relieved with intramuscular benztropine mesylate (Cogentin $\left.{ }^{(\otimes)}\right) .118$

Parkinsonism has been reported in six patients between 36 and 52 years of age, all of whom had consumed large amounts of common drugs for many years. ${ }^{119}$ The drugs included antihis- 
tamines; diphenydramine (Sominex ${ }^{\circledR}$ ), chlorpheniramine (Chlortripolon ${ }^{\circledR}$ ), dimenhydrinate (Dramamine ${ }^{\circledR}$ ) as an antinauseant; anorexiants, dextro-amphetamine and diethylpropion (Tenuate ${ }^{\circledR}$ ) as well as the sympathomimetic nasal spray xylometazoline (Otrivin $\left.{ }^{\circledR}\right)$. One used trimethoprim-sulphamethoxazole $\left(\right.$ Septra $\left.{ }^{\circledR}\right)$ for seven years. The structural and pharmacological similarities between some antihistamines and the phenothiazines suggest the former can produce dyskinesiae and parkinsonism if used over a long enough time. Oral/facial dyskinesiae associated with prolonged antihistamine use have been reported in two patients both with reduced homovanillic acid accumulation induced by probenecid loading. Improvement and worsening of the symptoms were related to the blind consecutive withdrawal and re-establishment of the medication. 120

Included in the more bizarre examples of reversible parkinsonism are a 47 year old female who developed the classic signs and symptoms after the intramuscular injection of procaine ${ }^{121}$ and a 78 year old woman with reversible parkinsonism and peripheral neuritis after taking perhexiline maleate for intractible angina pectoris. 122

The beta adrenergic blocker pindolol combined with clopamide used in the treatment of hypertension has been reported as causing or precipitating parkinsonism in two patients ${ }^{123}$ and meperidine ${ }^{124}$ as well as the neuroleptanalgesic mixture of fentanyl and droperidol have each produced a reversible parkinsonism.

Intraventricular amphotericin B has produced both transient and permanent parkinsonism ${ }^{125}$ as has intravenous cephalosporin. 126 Pseudo and idiopathic hypoparathyroidism may present as parkinsonism. Correction of the hypocalcaemia improves the neurological condition. 127

Metoclopramide, a benzamide neuroleptic, used as an antinauseant and anti-emetic has dopamine antagonist properties. It commonly provokes tardive dyskinesiae and can produce parkinsonism in the same patient if taken long enough. ${ }^{128}$

\section{REFERENCES}

1. Langston JW, Ballard PA. Chronic parkinsonism in humans due to a meperidine-analog synthesis. Science 1983; 219: 979-980.

2. Ballard PA, Tetrud JW, Langston JE. Permanent human parkinsonism due to 1-methyl-4-4 phenyl-1,2,3,6-tetrahydropyridine (MPTP). Neurology 1985; 35: 949-956.

3. Calne DB. Progress in Parkinson's disease. N Engl J Med 1984; 310: 523-524.

4. Snyder SH. Parkinson's disease: clues to aetiology from a toxin. Nature 1984; $311: 514$.

5. Rajput AH, Offord KP, Beard CM, et al. Epidemiology of parkinsonism: incidence, classification, and mortality. Ann Neurol 1984; 16: 278-282.

6. Eldridge R, Rocca WA. The clinical syndrome of striatal dopamine deficiency: parkinsonism induced by MPTP. N Engl J Med 1985; 313: 1159-1160.

7. Duvoisin RC, Schweitzer MD. Paralysis agitans mortality in England and Wales 1885-1962. Br J Prev Soc Med 1966; 20: 27-33.

8. Kurland LT. Epidemiology: incidence, geographic distribution, and genetic considerations. In: Fields WS, ed. Pathogenesis and Treatment of Parkinsonism. Springfield, Illinois: Charles C. Thomas, 1958; 5-49.

9. Calne S, Schoenberg B, Martin W, et al. Familial Parkinson's disease: possible role of environmental factors. Can J Neurol Sci 1987; 14: 303-305.
10. Golbe LI, Duvoisin RC, Miller DC. A large kindred with autosomal dominant Parkinson's disease. Ann Neurol 1988; 24: 151152.

11. Marguilies ME. Parkinsonism and brain tumor. Arch Neurol Psychiat 1953; 70: 112-113.

12. Carlsson A, Lundquist M, Magnusson T. 3,4 Dihydroxyphenylalanine and 5-hydroxytryptophan as reserpine antagonists. Nature 1957; 180: 1200.

13. Gordon JH, Koller WC. Animal models used to evaluate potential antiparkinson drugs. In: Koller WC, ed. Handbook of Parkinson's Disease. New York: Marcel Dekker Inc. 1987; 288289.

14. Janssen PAJ, Jageneau AH. A new series of potent analgesics. J Pharm Pharmacol 1965; 10(1): 14-21.

15. LaVerne A. Compendium of neuropsychopharmacology. J Neuropsychiat 1961; 2: 280-286.

16. Stimmel GL. Tardive dyskinesia with low-dose, short-term, neuroleptic therapy. Am J Hosp Pharm 1976; 33: 961-963.

17. Gerlach J, Simmelsgaard H. Tardive dyskinesia during and following treatment with haloperidol, haloperidol+biperidin, thioridazine, and clozapine. Psychopharmacology (Berlin) 1978; 59: 105-112.

18. Anderson BG, Reker D, Cooper TB. Prolonged adverse effects of haloperidol in normal subjects. Letter. N Engl J Med 1981; 305: 643-644.

19. Gelenberg AJ, Mandel MR. Catatonic reactions to high potency neuroleptic drugs. Arch Gen Psychiat 1977; 34: 947-950.

20. Flaherty JA, Lahmeyer HW. Laryngeal-pharyngeal dystonia as a possible cause of asphyxia with haloperidol treatment. Am J Psychiatry 1978; 135: 1414-1415.

21. Ellenhorn MJ, Barcelous DG. Medical Toxicology. New York: Elsevier 1988.

22. Corsini GU, Del Zompo M, Spissu A, et al. Parkinsonism by haloperidol and piribedil. Psychopharmacology 1978; 59: 139141.

23. Chase TN, Woods AC, Glaubiger GA. Parkinson disease treated with a suspected dopamine receptor agonist. Arch Neurol 1974; 30: 383-386.

24. Carlsson A. Receptor-mediated control of dopamine metabolism. In: Usdin E, Bunney WE, eds. Pre- and postsynaptic receptors. New York: Marcel Dekker 1975; 49.

25. Bunney BS, Aghajanian GK. Evidence for drug actions on both pre- and postsynaptic catecholamine receptors in the CNS. In: Usdin E and Bunney WE, eds. Pre- and postsynaptic receptors. New York: Marcel Dekker 1975; 122.

26. Steck H. Le syndrome extra-pyramidal et diencephalique au cours des traitments au forgactil au serpasil. Ann Med Psychol 1954; 1: 737-743.

27. Seeman $P$. The membrane actions of anesthetics and tranquilizers. Pharmacol Rev 1972; 24: 583-655.

28. Spector $S$, Gordon R, Sjoerdsma A, et al. End-product inhibition of tyrosine hydroxylase as a possible mechanism for regulation of norephinephrine synthesis. Mol Pharmacol 1967; 3: 549-555.

29. Javoy F, Agid Y, Bouvet D, et al. Feedback control of dopamine synthesis in dopaminergic terminals of the rat striatum. J Pharmacol Exp Ther 1972; 192: 454-463

30. Matthysee S. Antipsychotic drug actions: a clue to the neuropathology of schizophrenia. Fed Proc 1973; 32: 200-205.

31. Farnebo LO, Hamberger B. Drug-induced changes in the release of ${ }^{3}$ monoamines from field stimulated rat brain slices. Acta Physiol Scand 1971; 371 (Suppl): 35-44.

32. Kruse W. Development of parkinsonism after gradual reduction of fluphenazine dosage. Am J Psychiatry 1963; 119: 995-996.

33. Seeman P, Staiman A, Lee T, et al. The membrane actions of tranquilizers in relation to neuroleptic-induced parkinsonism and tardive dyskinesia. In: Forrest IS, Carr CJ, Usdin E, eds. The Phenothiazines and Structurally Related Drugs. New York: Raven Press 1974; 137-148.

34. Crowley TJ, Rutledge CO, Hohen MM, et al. Low urinary dopamine and prediction of phenothiazine induced parkinsonism: a preliminary report. Am J Psychiatry 1976; 133: 703-706. 
35. Cahan RB, Parish DD. Reversibility of drug-induced parkinsonism. Am J Psychiatry 1960; 116: 1022-1023.

36. Stratas NE, Phillips RD, Walker PA, et al. A study of druginduced parkinsonism. Diseases of the Nervous System 1963; 24: 180

37. Duvoisin RC. Problems in the treatment of parkinsonism. Adv Exp Med Biol 1977; 90: 131-155.

38. Rajput AH, Rozdilsky B, Hronykiewicz O, et al. Reversible druginduced parkinsonism. Arch Neurol 1982; 39: 644-646.

39. Wilson JA, Primrose WR. Drug-induced parkinsonism. (Letter) $\mathrm{Br}$ Med J 1986; 293: 957.

40. Stephen PJ, Williamson J. Drug-induced parkinsonism in the elderly. Lancet 1984; 2: 1082-1083.

42. Delay J, Deniker P, Thuillier J. Similitude des accidents nerveux de la prochorperazine avec certains troubles post-encephalitiques. Ann Med Psychol 1957; 115(3): 506-510.

43. Marie P, Levy G. Le syndrome excito-moteur de l'encephalite epidemique, ses principales manifestations; choree rhythmee brachycinesis et myoclonies parkinsonnisme. Rev Neurol (Paris) 1920; XXVII: 513-516.

44. Marie P, Levy G. Deux nouveaux cas de movements involuntaries post-encephalitiques: a localisation exclusivement lingulo-facio masticatrice. Bull et mem Soc med d hop de Par 1920; 3.S., XLIV: 546-552.

45. Marie P, Levy G. Un nouveau cas de localisation facio-masticatrice du syndrome excito-moteur tardif de l'encephalite epidemique avec manifestations de tic douloureux de la face. Bull et mem Soc med d hop de Par 1920; 3.S., XLIV: 661-664.

46. Hunter R, Earl CJ, Thornicroft S. An apparently irreversible syndrome of abnormal movements following phenothiazine medication. Proc Roy Soc Med 1964; 57: 758-762.

47. Klawans HL, Bergen D, Bruyn GW. Prolonged drug-induced parkinsonism. Confin Neurol 1973; 35: 368-377.

48. Hirschberg E. Long persisting drug-induced parkinsonism - a case report. Pharmacopsychiatria 1987; 20: 278.

49. Schwab RS, England AC. Parkinson syndromes due to various specific causes. In: Vinkenpt, Bruyn GW, eds. Handbook of Clinical Neurology, Vol. 6. Diseases of the Basal Ganglia. New York, Wiley 1968; 227-247.

50. Demars JPCA. Neuromuscular effects of long term phenothiazine medication, ECT, and leucotomy. J Nerv Ment Dis 1966; 143 170-176.

51. Murdoch PS, Williamson J. A danger in making the diagnosis of Parkinson's disease. Lancet 1982; i: 1212-1213.

52. Crane GE. Parkinsonism and tardive dyskinesia. (Letter) Am J Psychiatry 1978; 135: 619 .

53. Edelstein H, Knight RT. Severe parkinsonism in two AIDS patients taking prochlorperazine. (Letter) Lancet 1987; ii: 341342.

54. Nath A, Jankovic J, Pettigrew LC. Movement disorders and AIDS. Neurology 1987; 37: 37-41.

55. Davis GC, Williams AC, Markey SP, et al. Chronic parkinsonism secondary to intravenous injection of meperidine analogues. Psychiatry Res 1979; 1: 249-254.

56. Langston JW, Ballard P, Tetrud JW, et al. Chronic parkinsonism in humans due to a product of meperidine-analog synthesis Science 1983; 219: 979-980.

57. Langston JW, Ballard PA. Parkinson's disease in a chemist working with 1-methyl-4-phenyl-1,2,5,6-tetrahydropyridine. (Letter) N Engl J Med 1983; 309: 310.

58. Heikkila RE, Manzino L, Cabbat FS, et al. Protection against the dopaminergic neurotoxicity of 1-methyl-4-phenyl-1,2,5,6, tetrahydropyridine by monamine oxidase inhibitors. Nature 1984; 311: 467-469.

59. Markey SP, Johannessen JN, Chiueh CC, et al. Intraneuronal generation of a pyridinium metabolite may cause drug-induced parkinsonism. Nature 1984; 311: 464-467.

60. Greenfield JG, Bosanquet FD. The brainstem lesion in parkinsonism. J Neurol Neurosurg Psychiatry 1953; 16: 213-226.

61. Gupta SK, Murphy RC, Chandra SV. Neuro-melanin in manganese-exposed primates. (Letter) Toxicology 1980; 6: 17-20.
62. Lyden A, Bondesson U, Larsson BS, Lindquist NG. Melanin affinity of 1-methyl-4-phenyl-1,2,5,6-tetrahydropyridine, (Letter) Acta Pharmacol Toxicology 1983; 53: 429-432.

63. Langston JW, Irwin I, Langston EB. Parygline prevents MPTPinduced parkinsonism in primates. Science 1984; 225 : 1480 1482.

64. Javitch JA, D'Amato RJ, Strittmatter SM, et al. Parkinsonisminducing neurotoxin $\mathrm{N}$-methyl-4-phenyl-1,2,3,6-tetrahydropyridine: uptake of the metabolite $\mathrm{N}$-methyl-4-phenylpiridine by dopamine neurons explains selective toxicity. Proc Nat Acad Sci 1985; 82: 2173-2177.

65. Burns RS, LeWitt PA, Ebert MH, et al. The clinical syndrome of striatal dopamine deficiency-parkinsonism induced by Imethyl-4-phenyl-1,2,3,6-tetrahydropyridine. N Engl J Med 1985; 312: 1418-1421.

66. Uhl GR, Javitch JA, Snyder SH. Normal MPTP binding in parkinsonian substantia nigra: evidence for extraneuronal toxic conversion in human brain. Lancet 1985; 1: 956-957.

67. Javitch JA, Snyder SH. Uptake of MPP by dopamine neurons explains selectivity of parkinsonian-inducing neurotoxin. Eur J Pharm 1985; 10: 455-456.

68. Kopin IJ. MPTP: an industrial chemical and contaminant of illicit narcotics stimulates a new era in research on Parkinson's disease. Environ Health Perspec 1987; 75: 45-51.

69. Blair JA, Paween H, Parford IA. Aetiology of Parkinson's disease. Lancet 1984; 1: 167.

70. Leeming RJ, Pheasant AE, Blair JA. The role of tetrahydrobiopterin in neurological disease. J Ment Defic Res 1981; 25: 231-241.

71. Blair JA, Pearson AJ. Non-enzymatic, tetrahydrobiopterin mediated hydroxylation of phenylalanine. J Chem Soc Perk Trans 1975; 11: 245-249.

72. Forno LS, Langston J,W, Delanney LE, et al. Locus ceruleus and eosinophilic inclusions in MPTP-treated monkeys. Ann Neurol 1986; 20: 449-455.

73. Forno LS, Langston JW, Delanney LE, et al. An electron microscopic study of MPTP-induced inclusion bodies in an old monkey. Brain Res 1988; 448: 150-157.

74. Davis KL, Yesavage JA, Berger PA. Possible organophosophateinduced parkinsonism. J Nerv Ment Dis 1978; 166: 222-225.

75. Ohlson GG, Hogstedt C. Parkinson's disease and occupational exposure to organic solvents, agricultural chemicals and mercury - a case-referent study. Scand $J$ Work Environ Health 1981; 7: 252-256.

76. Barbeau A, Roy M. Genetic susceptibility, environmental factors and Parkinson's disease. 8th International Symposium on Parkinson's Disease. New York, June 9-12, 1985.

77. Boccheta A, Corsini GU. Parkinson's disease and pesticides. Lancet 1986; 2: 1163.

78. Peters HA, Levine RL, Matthews CG, et al. Carbon tetrachloride/carbon disulfide (80:20 fumigants) and other pesticides in grain storage workers. Acta Pharmacol Toxicol 1986; 59 (Suppl): 535-546.

79. Fahn S. Secondary parkinsonism. In: Goldensohn ES, Appel SH, eds. Scientific Approaches to Clinical Neurology. Philadelphia: Lea \& Febiger 1977. Vol. 2, 1169-70

80. Melamed E, Lavy S. Parkinsonism associated with chronic inhalation of carbon tetrachloride. Lancet 1977; i: 1015.

81. Kane FJ. Carbon disulfide intoxication from overdosage of disulfiram. Am J Psychiatry 1970; 127: 690-694.

82. Peters HA, Gocmen A, Cripps DJ, et al. Epidemiology of hexachlorobenzene-induced porphyria in Turkey: clinical and laboratory follow-up after 25 years. Arch Neurol 1982; 39: 744-749.

83. Sanchez-Ramos JR, Hefti F, Weiner WJ. Paraquat and Parkinson's disease. (Letter) Neurology 1987; 37: 728.

84. Koller WC. Paraquat and Parkinson's disease. (Letter) Neurology 1986; 36: 1147.

85. Koller WC. Paraquat and Parkinson's disease. (Letter) Neurology 1987; 37: 728. 
86. Carlsson A, Lindquist M. In vivo decarboxylation of a-methyldopa and a-methylmetatyrosine. Acta Physiol Scand 1962; 54: 87-94.

87. Groden BM. Parkinsonism occurring with methyldopa treatment. Br Med J 1963; 1: 1001

88. Peaston MJT. Parkinsonism associated with alphamethyl dopa therapy. Br Med J 1963; 2: 168.

89. Strang RR. Parkinsonism occurring during methyldopa therapy. Can Med Assoc J 1966; 95: 928-929.

90. Lutz EG. Neuroleptic-induced parkinsonism facilitated by alcohol. J Med Soc NJ 1978; 76: 473-474.

91. Lutz EG. Neuroleptic-induced akinisia and dystonia triggered by alcohol. JAMA 1976; 236: 2422.

92. Carlen PL, Lee MA, Jacob M, et al. Parkinsonism provoked by alcoholism. Ann Neurol 1981; 9: 84-86.

93. Lang AE, Marsden CD, Obeso JA, et al. Alcohol and Parkinson disease. Ann Neurol 1982; 12: 254-256.

94. Koller WC. Alcohol and Parkinson disease. Ann Neurol 1983; 13: 467.

95. McLean DR, Jacobs H, Mielke BW. Methanol poisoning: a clinical and pathological study. Ann Neurol 1980; 8: 161-167.

96. Ley CO, Gali FG. Parkinsonian syndrome after methanol intoxication. Eur Neurol 1983; 22: 405-409.

97. Lutz EG. Acute lithium-induced parkinsonism precipitated by liquid protein diet. J Med Soc NJ 1978; 75: 165-166.

98. Ringel SP, Klawans HL. Carbon monoxide-induced parkinsonism. J Neurol Sci 1972; 16: 245-251.

99. Harris B, Knapp MS. Sulfonylurea-induced hypoglycemia associated with unusual neurological features. Diabetes 1968; 17: 522.

100. Boranic M, Raci F. A parkinson-like syndrome as side effect of chemotherapy with vincristine and adriamycin in a child with acute leukaemia. Biomedicine 1979; 31: 124-125.

101. Bergevin PR, Patwardhan VC, Weissman J, et al. Neurotoxicity of 5-Fluorouracil. Lancet 1975; i: 410.

102. Chermat R, Simon P, Boissier JR. Amoxapine in experimental psycho pharmacology: a neuroleptic or an antidepressant? Arzneim Forsch 1979; 29: 814-820.

103. Charalampous KD. Amoxapine: a clinical evaluation in depressive syndromes. Curr Ther Res 1972; 14: 657-663.

104. Steele JE. Adverse reactions suggesting amoxapine-induced dopamine blockade. Am J Psychiat 1982; 139: 1500-1501.

105. Thornton JE, Stahl SM. Case report of tardive dyskinesia and parkinsonism associated with amoxapine therapy. Am J Psychiat 1984; 141: 704-705.

106. Lesser I. Case report of withdrawal dyskinesia associated with amoxapine. Am J Psychiat 1983; 140: 1358-1359.

107. El-Awar M, Freedman M, Seeman P, et al. Response of tardive and L-dopa-induced dyskinesias to antidepressants. Can J Neuro Sci 1987; 14: 629-631.

108. Strang RR. Imipramine in treatment of parkinsonism: a double blind placebo study. Br Med J 1965; 5452: 33-34.
109. Reiderer P, Reinolds GP. Deprenyl is a selective inhibitor of brain MOA-B in the long term treatment of Parkinson's disease. Br J Clin Pharmacol 1980; 9: 98-99.

110. Teusink JP, Alexopoulos GS, Shamoian CA. Parkinsonian side effects induced by a monamine oxidase inhibitor. Am J Psychiat 1984; 141: 118-119.

111. Weiner WJ, Nausieda PA, Klawans HL. Methylphenidate-induced chorea: case report and pharmacologic implications. Neurology 1978; 28: 1041-1044.

112. Casat CD, Wilson DC. Tics with combined thioridazinemethylphenidate therapy: case report. J Clin Psychiat 1986; 47: 44-45.

113. Gilman AG, Goodman LS, Gilman A. The pharmacological basis of therapeutics, 6th edition. New York: McMillan 1980; 555.

114. Klawans HL, Weiner WJ. The effect of d-amphetamine on choreiform movement disorders. Neurology (Minneap) 1974; 24: 312318.

115. Nausieda PA, Koller WC, Weiner WJ, et al. Chorea induced by oral contraceptives. Neurology 1979; 29: 1605-1609.

116. Leys D, Bourgeois P, Destee A, et al. Syndrome choreique et etat psychotique aigns provoques par une substance amphetaminique. Rev Neurol 1985; 146: 499-500.

117. Gilman AG, Goodman LS, Rall TW, et al. The pharmacological basis of therapeutics, 7th edition. New York: McMillan 1985; 156

118. Castellani S. Catatonia associated with phenylpropanoline overdose and fluphenazine treatment: case report. J Clin Psychiat 1985; 46: 288-289.

119. Ross RT. Young-age parkinsonism and common drugs. (Letter) Can J Neurol Sci 1989; 16: 366-367.

120. Thach BT, Chase TN, Bosma JF. Oral facial dyskinesia associated with prolonged use of antihistamine decongestants. N Engl J Med 1975; 293: 486-487.

121. Gjerris F. Transitory procaine-induced parkinsonism. J Neurol Neurosurg Psychiatry 1971; 34: 20-22.

122. Gordon M, Gordon AS. Perhexiline Maleate as a cause of reversible parkinsonism and peripheral neuropathy. J Am Geriat Soc 1981; 29: 259-262.

123. Lervy B. Parkinson's disease on treatment with viskaldix. J R Coll Gen Pract 1984; 34: 184

124. Lieberman AN, Goldstein M. Reversible parkinsonism related to meperidine. N Engl J Med 1985; 8: 509.

125. Fisher JF, Dewald J. Parkinsonism associated with intraventricular amphotericin B. J Antimicrob Therap 1983; 12: 97-99.

126. Mintz U, Liberman UA, Vries A. Parkinsonism syndrome due to cephaloridine. JAMA 1971; 216: 1200.

127. Pearson DWM, Durward WF, Fogelman I, et al. Pseudohypoparathyroidism presenting as severe parkinsonism. Postgrad Med J 1981; 57: 445-447.

128. Kataria M, Traub M, Marsden CD. Extrapyramidal side-effects of metoclopramide. Lancet 1978; 2: 1254-1255. 